\title{
An Evolutionary Transparency Approach to Public Accountability
}

\author{
Luca Anselmi ${ }^{*}$,Vincenzo Zarone ${ }^{* *}$, Sandro Brunelli ${ }^{* * *}$
}

\begin{abstract}
The concept of accountability reflects the growing importance that transparency has assumed in Italy and elsewhere. The evolutionary path of transparency in the Italian public sector from the post-war period to the present day emerges as in increasingly pervasive transparency, both in form and substance. The general, specific, and prospective guidelines are aimed at: strengthening the constitutional principles of impartiality and the good performance of public administrations; increasing the efficiency and effectiveness of public administration activities, safeguarding public finances and preserving public management legitimacy; measuring and externally communicating the value created; producing and organising meaningful data in support of open government policies to increase the welfare of the economy.
\end{abstract}

Keywords: Transparency; Accountability; Italy; Open Government Data; New Public Management; Global Markets; Public Administration

\section{New Public Management and Transparency}

This paper deals with the evolution of the notion of transparency, with particular reference to the Italian public sector. This topic is particularly relevant due to the traditional "public" and "political" connotation of the disclosure of relevant information on the activities, results, and resources of public entities. The "public" element refers to the necessary higher-level protection of public interests compared to individual and particular interests, also through qualified forms of interaction between citizens and authorities, through the instruments of "civic engagement and collaborative public management" (Cooper, Bryer \& Meek, 2006), which presuppose the full awareness of citizens of information on critical matters, such as the organization of public administrations, the framework of the objectives that inspire management, the levels of effectiveness and efficiency in achieving the objectives set.

\footnotetext{
*Full Professor of Management, University of Pisa (luca.anselmi@ unipi.it)

** Assistant Professor of Management, University of Pisa (vincenzo.zarone@unipi.it)

*** Assistant Professor of Management, University of Roma "Tor Vergata", (brunelli@economia.uniroma2.it)
} 
The "political" element consists in the imputability of choices made to a decisionmaking system in which the decision-making bodies are legitimized to make allocative choices beyond citizens, but towards whom they have responsibilities that also extend to adequate and timely information flows, so as to enable the community to exercise "widespread control" and foster forms of «discursive participation» (Carpini, Cook \& Jacobs, 2004).

The corpus of paradigmatic theories known as new public management (Hood, 1991, 1995) are inextricably bound to the reform processes that have concerned the public sector of western countries since the 1970s, with significant effects in Italy since the early '90s. From this decade, the information that public entities must disclose has broadened and widened, supplementing traditional accounting and budgeting information, public tenders, and administrative proceedings with a core of continually expanding information on matters whose knowledge is of "public interest". This broadening is linked to the changing and increasing needs of private individuals, intended as citizens but also private companies, to access public information as a result of transferring the responsibility of ensuring widespread fruition of essential public services to participating companies, public-private companies, or public companies with private legal status.

This paper considers these complex themes within the broader framework of public accountability. Section 2 provides a literature review of the broad concept of accountability and the role that transparency assumes within the wider notion of accountability. The literature review is divided into two parts: the first from the 1980 s to the early 2000s - the period when scholars focused on the meaning of the term accountability and the various lines of inquiry ascribable to it; the second from the beginning of the 2000s to today - a period when scholars, given the impossibility of agreeing on a decisive definition, proposed different methodologies to provide evidence in different contexts of what accountability entails for the prevailing recipients, how to improve current accountability processes, and how to avoid the overproduction of information. This second part includes numerous studies around financial accountability, which remains the main driving force of accountability also with reference to public entities.

In the attempt to outline some fundamental stages in the "paradigm shift" that took place in the Italian context, the third section describes those characterising the notion of transparency in terms of the regulations and effects on the organization and management of public entities. The last section offers some final considerations, describing some current and prospective development directives that redefine the notion of transparency.

\section{Transparency within the Broader Concept of Accountability}

In literature, the term accountability emphasises different aspects including transparency and responsibility. In the public domain, the concept of accountability has evolved due to the various changes in public administration management since the late 1980s.

Although this concept is continuously evolving, literature broadly converges on the fact that accountability has shifted from a concern for respecting procedures and 
regulations to a marked emphasis on processes and results. In a context of growing social complexity, transparency has acquired increasing scope, both in the public and private sectors. If this is a general tendency all over the world, in Italy, especially with reference to the public sector, it has reached previously unimaginable levels.

As we shall see in the following, transparency has always been given due consideration in the Italian context, but in different ways and with different means, and sometimes with delays in relation to the affirmation of the concept in society. Already in 1988, Klitgaard mentioned the term accountability, intended as the summation of transparency and controls, as a key factor for a successful strategy to fight against corruption. In fact, the author deemed that thanks to accountability, two key enablers of corruption could be disabled: monopoly of power and excessive discretion that may be singularly or collectively concentrated in the hands of managers. This is also the case in emerging economies striving for transparency in the fight against corruption (Pepe et al., 2014).

Today, through an express provision (Legislative Decree 33/2013, art. 2), transparency in Italy is intended as full access to data and documents held by public administrations, no longer only to "facilitate widespread forms of control over the pursuit of institutional functions and on the use of public resources", but above all, and significantly, as a tool to protect the rights of citizens and to promote the participation of those concerned with administrative affairs. This concept of transparency, as we will see, entails numerous means of delivering accountability.

Returning to the concept of accountability, the many contributions over time can be divided into two time blocks. In the first, from 1980 to 2000, the contributions relate to a conceptual exploration of accountability. The attempt on the academic side was to arrive at a decisive definition, and on the policymakers' side, to foster widespread forms of control based on different approaches and needs.

Without claiming exhaustiveness, the most decisive contributions in literature can be summarized as follows, whereby accountability:

- $\quad$ is the result of different combinations of rationality (Gray \& Jenkins, 1993);

- evolves (Guthrie, 1993): formerly seen only as providing formal accountability of activities at the higher institutional levels and subsequently providing accountability for the market that according to its judgment, awards the related premiums or sanctions;

- is proposed with reference to tasks or results (Stewart, 1984) or as others argue (Taylor \& Rosair, 2000), with reference to regulations/procedures or efficiency/effectiveness;

- has a magnitude based on the degree of autonomy of the agent and the expectations and powers of control of the principal (hierarchical, legal, professional, political) (Johnston \& Romzek, 1999);

- is a function of different points of observation pertaining to responsibility, the subjects involved, and established standards (Barberis, 1998);

- turns the focus towards the individual (the single company in public companies) or towards the community (Roberts, 1996);

- is essentially an analysis of deviations from predefined standards and outcomes decided during programming (Kearns, 2003); 
- is vertically transversal to organizations: top down (downward accountability) or bottom up (upward accountability) (Stone, 1995);

- is a function of the various duties of the individual or organisation that must provide accountability (Rubin, 1996);

- lends itself to subjective categorizations not bound to a particular interpretation, but adding aspects of public life and contributions from prior studies (Sinclair, 1995).

With the new millennium, scientific contributions on the theme in part diminished and in part evolved. With reference to the former, it became clear that arriving at a shared definition was no longer feasible given the large number of elements and aspects that accountability entails. With reference to the latter, an era of studies began aimed at:

- Offering evidence of how to provide accountability for certain contexts, especially due to the many solutions proposed in the previous period (Pallot, 2001; Posnen, 2006; Bello, 2013; Fowler \& Coredry, 2015; Mutiganda, 2013; Pollanen, 2015; Haraldsson, 2016; Kwan et al., 2016).

- Studying the existing frameworks and proposing improvements (Kassel, 2008; Kulshreshtha, 2008; Barrett, 2014; Palyi, 2015).

- Continuing on Klitgaard's path of accountability as a key tool to fight against corruption (Akbar \& Vujic, 2014).

- Considering the evolution of financial accountability as accountability par excellence, traversing specific temporal conditions, deserving the greatest attention and the need for improvements (Torres, 2004; Carnegie \& West, 2007; Bracci et al., 2015; Reginato, 2010; Heald \& Georgiu, 2011; Grossi \& Steccolini, 2015; Mir \& Rahaman, 2007; Newberry, 2015; Rodriguez Bolivar et al., 2015).

- Highlighting the risk of overproduction of information, with the consequent risk of drastically decreasing the quality of information (Christensen \& Skaerbaek, 2007).

Mulgan (2000) identified a number of key characteristics that must necessarily exist to qualify the concept of accountability, amongst which the greater complexity of the concept of the public domain by reason of the agency relationship that unfolds among three main principals: politicians, administrations, and citizens. An important aspect, especially with regard to public administrations, is the link between whoever provides accountability, and those receiving and evaluating it. In particular, in some cases, accountability derives from specific obligations (and thus in all respects within an agency relationship), in other cases, one party is accountable to another on a voluntary basis.

Precisely the complexity and degree of obligation prompted scholars to consider accountability from different angles in view of the different profiles or levels. According to some authors (Giosi et al., 2010; Brunelli et al., 2011), there are four prevalent levels of accountability involving politicians, administrations, and citizens:

1. Political accountability, wherein the political and administration relationship develops, where the latter is accountable to the former in terms of the operational procedures followed to implement the directives received ${ }^{\mathrm{i}}$. 
2. Social accountability, where the political level is accountable to the public on how it has intervened in the economic and social context, demonstrating whether or not the needs expressed by the community have been met through defining and implementing public policies.

3. Internal accountability, where the administration simultaneously plays the role of principal and agent. Indeed, on the administrative level, there is constant monitoring and control over the activities to continually redefine the priorities and the ways in which to follow the directives from the higher institutional level. In this context, the success of accountability is in the degree of structuring and in the logical consistency of the internal control systems.

4. External accountability, where the public administration comes in direct contact with the community. At this level, based on the evidence provided, the community evaluates the administrative work. The outcome of the evaluation constitutes fundamental feedback to redefine the strategies to be adopted on the political level and the operational plans to be put in place on the administrative level to effectively respond to petitions from citizens.

Figure 1: Accountability Profile

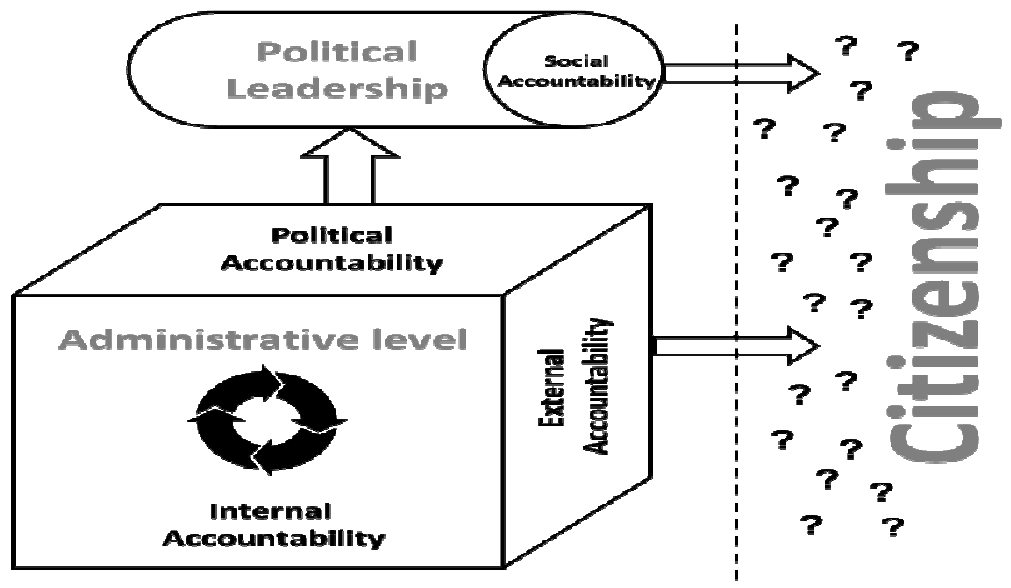

Extant literature deems that three key aspects of public sector accountability have not been duly highlighted or analysed in depth:

1. The political accountability level has almost exclusively been conceived as a relationship between politicians and citizens, without taking into account the importance of ongoing and existing (or that should exist) negotiations between politicians and administration, including, if not above all, informal.

2. The lack of specific insights on administrations concerning the dynamics of the accountability process in the presence of decentralization or centralization in many jurisdictions (for example, both have occurred in Italy over a period of only twenty years).

3. The various conceptions of accountability do not attribute importance to the mutual influences that exist between on the one hand accountability processes and planning, programming, and control processes, and on the other, financial and budgetary programming. 
Precisely because of these aspects, the principal instrument of transparency could represent the information leap that is not only required but also fuels public debate on how to manage resources, which largely determines the effectiveness, efficiency, and cost-effectiveness of the functioning of public administrations. It is no coincidence that the transparency tools available in the Italian system have seen three instances of integration, exponentially increasing the degree of transparency to which public administrations are subject:

1. In the early 1990s, access to documentation was introduced, namely, the possibility for one or more parties with a direct, actual, and current legal interest to request access to acts the public administrations have put in place;

2. In 2009, such access was supplemented with civic access, namely, the possibility for anyone, irrespective of a legally relevant interest, to request access to acts, documents, and information subject to disclosure obligations as provided for by law and which the administration has failed to publish;

3. In the 3.0 era of transparency (2016), generalized access was finally established as the possibility for any citizen, irrespective of any particular interest, to access any public administration information beyond those subject to mandatory disclosure. In such cases, however, exceptions apply for reasons of privacy, state secrecy, or other cases in which the disclosure of information may harm other legally relevant interests.

The Freedom of Information Act (FOIA), which introduced generalized access, has done nothing other than align the Italian transparency discipline with those already present in other nations, especially the Anglo-Saxon. This last step is the result of a very long journey that gained momentum in the 1960s.

\section{The Notion of Transparency: Object, Subjects, and Evolutionary Profiles}

Transparency in the public sector, as highlighted in the previous section, has instrumental value in the wider concept of accountability. However, the instrumentality of the notion does not constitute a limit to the vast forms and ways in which transparency manifests, but refers only to an organic link with the necessary accountability that public administrations cannot avoid, also (and even more so) by virtue of the nature and purpose of public organizations.

Among the various meanings that transparency assumes in Italian law, one of the most important is that of "right of access", reported amply in literature (among others, Héritier, 2003), which has been explicitly formulated as a regulatory provision for several decades and is progressively affirming, gaining increasingly broader meaning.

The objects of the right of access include: the deliberations that public administrations adopt and that affect the sphere of citizens' rights; the "administrative procedure", understood as the logical-legal procedure from which the deliberation originates; in the most recent and widespread sense, access also to qualified information on the organization of individual units and the allocation of resources, thus irrespective of the necessary link with subjective and legitimate 
interests that limit the disclosure perspective to the individual dimensions of the those seeking access.

The main actors of the right of access to public administration acts were formerly individual citizens interested in the content of the public deliberations and related effects on their rights, and public administrations implementing a series of multiple and different activities up to producing the deliberation.

The stratification of regulatory provisions, as discussed later in the section, has extended the scope of the notion of transparency and right to access as regards the object (the Freedom of Information Act also refers to data and information for which there is no specific disclosure obligation) and as regards those legitimately entitled to access information, namely, citizens, as individuals or organized groups, who need not demonstrate the legitimacy of their interests in claiming qualified and relevant feedback from public administrations.

Right of access has long been established as a true general principle characterizing administrative activities; the underlying purposes of this important provision are at least twofold:

- An "active" objective aimed at the effective participation of citizens in the activities of public administrations: through awareness and the greater intelligibility of acts, the identification of those in charge of the proceedings, the need to justify the measure that the public administration implemented, and numerous other implications of the process of partial "privatization" of administrative law, which determined (substantially from the early 1990s) new relation modes between citizens and public individuals, which cannot be deemed to be on the same level (an appropriate difference remains in relation to acts of an authoritative nature), but certainly seem more balanced.

- A greater focus on widespread control, both internal and external to public organizations, aimed at strengthening the constitutional principles of ensuring impartiality and the good performance of public administrations.

The latter objective is achieved through the use of the forms of "transparency" mentioned above in relation to the "active" objective, but is enriched by specialization of information flows in particularly relevant areas of the life of public administrations, such as corruption prevention and the measurement and evaluation of individual and organizational performance.

Numerous evolutionary stages have contributed to the definition of the notion of the thus structured concept of transparency as "right of access", which today is defined as the "right of full access", assuming a hyperbolic type definition when due to relevant cautions in terms of "cost and benefits" there is no access to publicsector information (Blakemore \& Craglia, 2006), and in terms of more specific confidentiality issues that the implementation of public action inherently requires.

From the legal system perspective, without going too far back in time, some key transitions should be mentioned that led to configuring the current notion of transparency and right of access in the Italian context. Indeed, such right was not recognized to citizens until the first half of the 60's: administrative activities were inspired predominantly by a general principle of secrecy, which did not permit knowledge of the procedures to external users (in either the preparatory or the investigative phases). 
This right gradually expanded, initially with reference to specific sectors: with Law 765 of 1967 concerning the issue of building permits and related acts; with Law 349 of 1986 concerning the possibility of access to environmental information.

From observing the significant changes in Italian legislation and the consequent revisiting of the functioning of public administrations, some crucial phases can be identified from the early 1990s to the present:

- The reformulation of substantive aspects of administrative procedure with Law 241 of 1990, which introduced some fundamental instruments of transparency, also in terms of citizen participation, but establishing a concept of "collateral" transparency in the conduct of administrative activities and not intrinsically linked (so much so that, as will be discussed later, in the original version of the regulatory measure, reference is made to the "disclosure" criterion and not to the concept of "transparency"; the latter explicitly referred to several years later with Law 15 of 2005).

- The affirmation of the principle of full access with Legislative Decree 150 of 2009: the "change of gear" with respect to the more limited concept in the original version of Law 241 of 1990 is evidenced by the reference to requisite public access to data relating not only to individual procedures and measures, but also to qualifying information on resource allocation, management trends, the inputs and outputs of activities of each public entity, to foster widespread forms of control by external observers;

- The timely revision of the "disclosure, transparency, and dissemination" obligations initiated by Legislative Decree 33 of 2013 and, by a not insignificant decision, adopted in the implementation of the delegation in the first Italian "AntiCorruption" law (Law 190 of 2012): apart from clarifying and strengthening the concept of full access to information on the organization and activities of public administrations, organically linking some documents that public administrations must draft and publish, namely, the Corruption Prevention Plan, the Performance Plan, and the Transparency and Integrity Program (which, with Decree 97 of 2016, was absorbed into a specific section of the anti-corruption plan).

- The introduction of a new form of access, a new channel with respect to that of information attributable to legally relevant subjective interests: in fact, with the provisions of Legislative Decree 97 of 2016, a civic access approach was adopted for public records and documents inspired by the Anglo-Saxon FOIA (Freedom of Information Act), which not only strengthened the civic access tools, but constituted a new and further form of access insofar as extended to data and documents that public administrations have no obligation to disclose.

More specifically, with regard to the content of the aforementioned measures, the provisions of Law 241 of 1990 (the so-called Administrative Procedure Act) are of undoubted importance from the very first passages of the regulatory text, namely, the "effectiveness, efficiency and disclosure criteria" that Article 1 ascribes to administrative activity.

The key principles of the 1990 law that have particular legal relevance and substantial implications on the organization and management of public administration activities include: the compulsory identification of those in charge of the procedures; foreseeing the establishment of public relation offices; notifying the start of the administrative procedures and public deliberation. 
Law 241/90, by identifying those in charge and the timely communication of the start of the procedures to those concerned therefore constitutes an explicit reference of the compliance of internal subjects (the public administrations producing the deliberation) and the rights of external subjects in terms of access to and knowledge of not only relevant information, but also the various steps involved in achieving the final measure and its effects on those concerned.

From a semantic point of view, using the term "transparency" is of primary importance to complete the significance of the certainly more restrictive term "disclosure". Reference to transparency ensued from Law 15 of 2005. The principle is based on knowledge of administrative actions, contrasting the public administrations' necessary adherence to a right, in many respects new and with boundaries that are not definable a priori, exercisable by external parties who must "see" and control the work of public entities.

From the point of view of the effect on the legal system, Law 15 of 2005 and then Law 69 of 2009 sought to achieve the integration of the list of criteria that must inspire the activities of public administrations. The current wording of Article 1 of Administrative Procedure Law 241 of 1990 refers to the previous criteria of "economic balance, effectiveness, disclosure" supplemented by "impartiality" and, in particular, the criterion of "transparency".

Among the substantial aspects of the notion of transparency, certainly important is the duty to state the reasons behind the administrative measure, recalling the issue of public management accountability, and as such, a relationship between citizens and administrations that is dialectically and diametrically opposed to the era of "secrecy" and the failure to share the legal path of acts that characterized the Italian system until the 1960s (to the point of the privatization of important aspects of administrative law as regards non-authoritative type acts with the approval of Law 15 of 2005).

More recently, Legislative Decree 33 of 2013 introduced a regulatory intervention specifically referring to the "reorganization of the rules concerning the obligations of disclosure, transparency, and dissemination of information by public authorities". This measure reiterated the concept of full access, making the right to know explicit and clarifying the fundamental mode (time, ways, safeguards) of socalled "civic access". The different obligations in terms of disclosure according to the type of information and the different categories of subjects requiring "accountability" would seem significant. The disclosure requirements concern:

- Generally public administration organization, staffing, and personnel costs (distinguishing permanent from fixed-time contracts), performance evaluations, distribution of staff premia, civil servant assignments, timing of payments (with publication of an annual indicator of the average payment period).

- Specific obligations related to particularly relevant parts of the public sector (such as regional health services, recalled in Article 41) or high-impact activities and issues, such as land-use and management, planning and executing public works, information on the environment, extraordinary and emergency interventions.

- Obligations relating to specific subjects: members of political bodies, provincial and regional council groups (drafting and publishing reports on resources received and used), holders of executive positions, collaborators or consultants, supervised 
public bodies, private-sector entities under public control, participation in private companies.

On the latter point, companies partly owned by public entities are specifically relevant by type of products and services, by number (the Court of Auditors in 2015 reported just under 8000 entities with only regional authorities' participation, see resolution no. 24/SEZAUT/2015/FRG) and the economic impact of their activities (in the aforementioned resolution, the Court of Auditors estimated the value of the revenues of those entities at around $€ 65$ billion). Alongside the reorganization and rationalization hypothesis, hitherto always disregarded, the legislation foresees an increasing flow of information produced and made available either by those participating or the entities themselves. For example, Law 33 of 2013 foresees the mandatory disclosure of the cost of each service rendered, the mode, and time of service provision, in addition to the information contained in the services charter or similar documents reporting the qualitative and quantitative standards of public services. This disclosure requirement is technically complex, both in terms of the level of detail of information to be made available for each individual participating company (for example, in highlighting costs, distinguishing those ascribable to staff for each service provided, assuming the availability of reliable and timely accounting data), and as regards the need to consolidate the accounts of the participating entities with those holding the participations. In this regard, public accounting systems have over the last decade been subject to a number of major reforms (initiated by Law 196 of 2009, which repealed the previous Law 468 of 1978), oriented towards the "harmonization" of accounting systems, the preservation of balance through strengthening the system of controls on spending, and greater transparency, expanding the information content of public budgets, greater intelligibility and comparability of documents concerning the public finance planning cycle. Greater transparency in the public sector, also through revising the accounting system, is furthermore advocated by international and supranational institutions (the International Monetary Fund, the European Central Bank, amongst others). Relevant here are both the EU Directive 2011/85/EU, which defines (with Articles 3-16) the obligation for all member countries to adopt public accounting systems that contain the necessary information to generate data based on the "accrual" principle, and the formulation (and ongoing revisions) of accounting standards for the public sector at the international level (IPSAS), and specific interpretations in the European context (EPSAS). The accounting system and the development of tools for systematic business reporting therefore emerge as fundamental "drivers" qualifying the most current and extensive notion of transparency in the public sector. The latest trends that reinterpret and extend the notion of transparency towards the Freedom of Information Act pose a significant issue not so much and not only in relation to disclosure, but also the quality and reliability of "open government data" (Viscusi et al., 2014), in relation to which the European context differs greatly in terms of practices, fundamental approaches, and implementation tools (Janssen, 2011). Regarding the data to process and disclose, the significance of open data is fundamentally linked to its usefulness to recipients, but also the reliability and timeliness of publication and updating. In this sense, the technical-accounting origin of much of the information disclosed by public administrations is an intrinsic guarantee of reliability (effective benchmarking is 
enabled by comparing the single data extracted with the accounting system, validated by internal and external controls to which the authorities are subject), and allows continuously updating the information provided, since compliance to financial statements is at times extended beyond the deadlines, but always mandatory and non-derogable. Consequently, in the Italian context, extending the right of access to data and multiple and diverse documents for which there is no general disclosure requirement has opened a new era of transparency. Appropriate at this point is organically conceiving the external disclosure of activities by calibrating the quality of information with respect to the growing expectations of citizens, while at the same time balancing the costs and benefits of wider and more detailed information flows, no longer referring to individual acts, but to a broader scope of issues characterized by considerable complexity. To support this change, an unavoidable step is the systematic use of information and communication technologies (ICTs), since the responsible use of e-government tools (not excluding forms of social media-based communication) is an efficient and "cost-effective" means of opening towards the outside and, in some cases, to fight corruption and maladministration (as frequently and accurately evidenced by empirical studies: amongst others, Bertot et al., 2010).

\section{The Paradigm Shift in the Notion of Transparency}

Transparency in Italy and the world has grown, certainly in terms of quantity of information disclosed or made available to the community. What remains difficult to understand is the extent and complexity of designing transparency paths for information that in fact already exists. Here the privacy-transparency oxymoron emerges. One wonders, then, to what extent and for what reasons (general or specific) privacy needs are relinquishable, a prerogative of the absolute transparency of public actions. In theory, espousing the meaning that transparency has assumed over time, we could easily conclude that privacy may even be completely relinquished by reason of the greater good that transparency constitutes. In practice, however, not only legal constraints exist, more or less marked in Italy as in other countries, but situations where privacy is still objectively something justifiable. Moreover, as mentioned in the introduction of this paper, the thirst for accountability (and therefore transparency) has grown for multiple reasons. Amongst these, with reference to Italy and in our opinion, the ever-greater interest among public and private interests is the flywheel with which greater transparency has permeated the Italian public sector. The reference is to concessions, deregulation, privatization, the use of the legal form of public corporations. These phenomena already developed not long after the end of World War II and during the twenty years of the Italian "economic miracle", which often due to lack of public management foresight continued growing and creating the contamination between the public and private domain, requiring transparency for the country's effective functioning in terms of the market for goods, labour, and capital (Brondoni, 2014; Lambin, 2014). In this sense, we could even speak of an era of globalization of transparency if many of the accountability aspects that embody transparency call for the deployment of rules, regulations, and common standards at 
the national and international level (Bisio, 2004; Brondoni, 2004; Gnecchi, 2004; Rebora, 2004). Consider the accounting harmonization dynamics in place since the early 70's in the private sector through the creation of the International Accounting Standards Board (IASB, at the time the International Accounting Standards Committee, IASC) and a little later, in the mid-80s, the creation of the International Public Sector Accounting Standards Board (IPSASB, then Public Sector Committee, PSC). The common thread was and is the greater comparability of data, which translates into greater intelligibility, and ultimately greater transparency. Thus, starting from pioneering financial accountability and the tools and solutions (not without problems) that this offers, transparency has and continues to race towards a higher objective: the aforementioned trajectory of open government data useful for the production of effective policies for the overall wellbeing of the economy. Figure 2 below summarizes some of the most relevant characteristics of the development of the notion of transparency. The shift towards the Freedom of Information Act approach has entailed a broadening of the subjects involved, to the extent that the recipient of public disclosure is not only the individual citizen legitimated by a relevant legal interest, but the community of reference as a whole.

The objects of transparency have also broadened: originally attributed to the single public deliberation or certain stages of the administrative procedure, gradually extending to multiple and complex objects, up to and including public disclosure of data and information that public administrations have no specific obligation to disclose. The most obvious consequence of this "incremental paradigm" is the enormously increased organizational complexity for public administrations that have to produce and organize new information flows that are no longer standardized, and often technically complex (such as those on anticorruption, performance, activities of participating companies, amongst others).

Figure 2: The Paradigm Shift: From Old to New Transparency in the Italian Public

Sector

\section{Transparency}
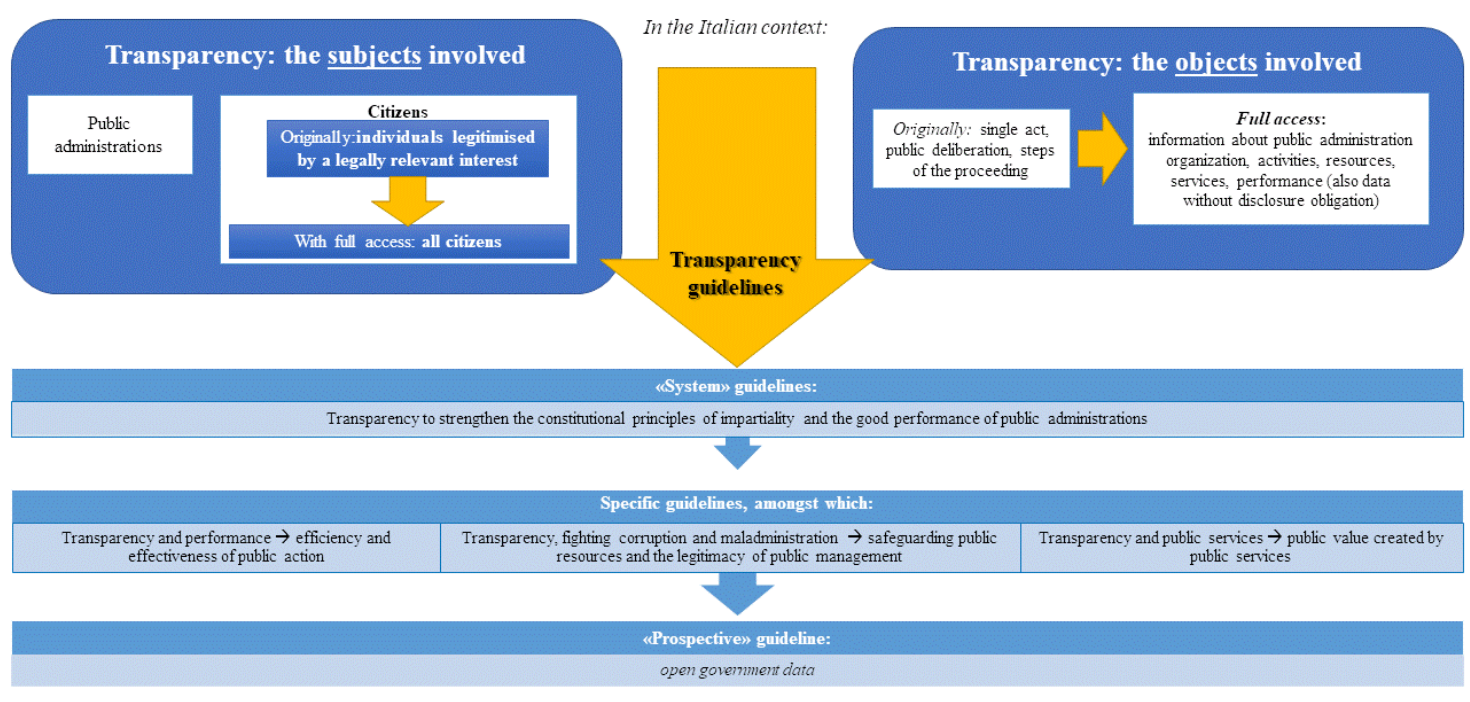
In addition to the definition of the subjects and recipients of the communication flows that substantiate the concept of transparency, the changes that occurred in the Italian legal system developed according to some fundamental guidelines concerning crucial aspects of the internal organization of public entities and the relationships they establish with the external environment:

- A general and far-reaching guideline aimed at strengthening the constitutional principles of impartiality and good performance of public administrations.

- A series of specific guidelines:

- efficiency and effectiveness of public actions related to the regulations on transparency of the performance (individual and organizational) of public administrations (started with Decree 150 of 2009);

- safeguarding public resources and preserving the "legitimacy" of public management (D'Onza et al., 2017; Curtin \& Meijer, 2006) related to the obligations in the sphere of external disclosure (from multi-year plans to dedicated reports) of continuous corruption prevention activities (Law 190 of 2012) to be achieved by identifying and mapping the most risky processes and the appropriate forms of intervention on organizational structures;

- measurement and external communication of the value created by public services through reports on the activities (Salvioni and Bosetti, 2014) of the participating entities of public bodies, made more significant by the accounting system reform launched in 2009 and inspired by the harmonization and greater intelligibility of both accounting and nonaccounting information (about governance, for example, as provided by Law 124 of 2015, particularly Legislative Decrees 175 of 2016 and 100 of 2017);

- A prospective guideline: the production and organization of data in support of open government policies: essential in this perspective is the quality of information produced in terms of significant, intelligible and timely usable open data.

In essence, transparency is affirmed both on the level of regulations and resulting managerial implications as a true "essential level of provisions relating to social and civil rights", recalling anti-corruption Law 190 of 1990.

As a result, both in the case of transparency on performance and in response to the anti-corruption obligations, in view of the need to publish plans and reports that disclose the relevant elements of the performance cycle and activities undertaken to prevent and combat fraudulent instances of maladministration, public entities have at least become more aware of their own organizational structure and some of the critical issues related to "riskier" management activities and processes.

This result is far from insignificant. Driven by the need to provide relevant information to the outside, it would seem reasonable to assume that the widespread control pressure increases awareness and preludes the possibility of improving operating conditions. Assuming particular importance, especially prospective, is the obligation for more accurate disclosure of management developments (through consolidated financial statements) and the governance variables of participating companies. In fact, this requirement can raise awareness both internally and 
externally on the dispersive and heterogeneous composition of public groups (local and not only): also in this case, the "widespread control mechanisms" of citizens, the continuously shrinking resources available for services that have a considerable impact on the community, can exert much more decisive pressure than the bland normative references of recent years, in the perspective of better focusing the public sector perimeter.

The increased awareness, which seems reasonable to postulate, and the more sophisticated and functional instruments to support external disclosure are inexorably linked to the possible transition towards open government. These instruments, however, will have to be linked to a strong commitment to achieve substantial acts of volition: the management of public administrations may be deemed "open" in its full meaning if the renewed "business" culture, and not merely formal compliance, determine the disclosure approaches.

\section{Bibliography}

Akbar, Y. H. \& Vujić, V. (2014). Explaining Corruption the Role of National Culture and Its Implications for International Management. Cross Cultural Management. 21 (2), 191-218. https://doi.org/10.1057/palgrave.jibs.8400262

Barberis, P. (1998). The New Public Management and a New Accountability. Public Administration, 76 (4), 451-470. doi:10.1111/1467-9299.00111

Barrett, P. (2014). New Development: Financial Reform and Good Governance. Public Money \& Management. 34 (1), 59-66. https://doi.org/10.1080/09540962.2014.854987

Bello, H. (2013). Audit Committee's Role in Enhancing Accountability of the Albanian, Public Sector. European Journal of Business \& Economics. 8 (4), 29-40.

Bertot, J. C., Jaeger, P. T., \& Grimes, J. M. (2010). Using ICTs to Create a Culture of Transparency: E-government and Social Media as Openness and Anti-Corruption Tools for Societies. Government Information Quarterly, 27(3), 264-271. https://doi.org/10.1016/j.giq.2010.03.001.

Bisio, L. (2004). Global Market and Public Governance in Europe. Symphonya: Emerging Issues in Management (symphonya.unimib.it), 1, 69-81.

http://dx.doi.org/10.4468/2004.1.07bisio

Blakemore, M. \& Craglia, M. (2006). Access to Public-Sector Information in Europe: Policy, Rights, and Obligations. Information Society, 22(1), 13-24. https://doi.org/10.1080/01972240500388180.

Bracci, E., Humphrey, C., Moll, J. \& Steccolini, I. (2015). Public Sector Accounting, Accountability and Austerity: More Than Balancing the Books? Accounting, Auditing \& Accountability Journal. 28(6), 878-908. https://doi.org/10.1108/AAAJ-06-2015-2090

Brondoni, S.M. (2004). Ouverture de 'Public Governance and Global Markets'. Symphonya. Emerging Issues in Management (symphonya.unimib.it), 1, 1-4. http://dx.doi.org/10.4468/2004.1.010uverture

Brondoni S.M. (2014). Global Capitalism and Sustainable Growth. From Global Products to Network Globalisation. Symphonya: Emerging Issues in Management (symphonya.unimib.it), $\mathrm{n}$. $1,1-4$. http://dx.doi.org/10.4468/2004.1.010uverture

Broadbent, J., Jacobs, K. \& Laughlin, R. (1999). Comparing Schools in the UK and New Zealand: Individualising and Socialising Accountabilities and Some Implications for Management Control. Management Accounting Research. 10(4), 339-362. https://doi.org/10.1006/mare.1999.0113

Brunelli, S., Giosi, A. \& Testarmata, S. (2011). Agencies as Instruments of New Public Management: Models of Accountability in Italy, in Osborne S.P. \& Ball, A. (ed.). Social Accounting and Public Management. Accountability for the Public Good. London: Routledge.

Carnegie, G.D. \& West, B.P. (2005) Making Accounting Accountable in the Public Sector. Critical Perspectives on Accounting. 16(7), 905-928. https://doi.org/10.1016/j.cpa.2004.01.002 
Carpini, M.X.D., Cook, F. L. \& Jacobs, L. R. (2004). Public Deliberations, Discursive Participation and Citizen Engagement: A Review of the Empirical Literature. Annual Review of Political Science. 7(1), 315-344. https://doi.org/10.1146/annurev.polisci.7.121003.091630

Cochrane, A. (1993). From Financial Control to Strategic Management: The Changing Faces of Accountability in British Local Government. Accounting, Auditing and Accountability Journal. 6(3), 30-51. https://doi.org/10.1108/09513579310042551

Cooper, T.L., Bryer, T.A. \& Meek, J.W. (2006). Citizen-Centered Collaborative Public Management. Public Administration Review. 66(Special Issue), 76-88. https://doi.org/10.1111/j.1540-6210.2006.00668.x.

Christensen, M. \& Skærbæk, P. (2007). Framing and Overflowing of Public Sector Accountability Innovations. Accounting, Auditing \& Accountability Journal. 20 (1), 101-132. https://doi.org/10.1108/09513570710731227

Curtin, D. \& Meijer, A. J. (2006). Does Transparency Strengthen Legitimacy? Information Polity, 11, 109-122. https://doi.org/10.2139/ssrn.1434862

D’Onza, G., Brotini, F. \& Zarone, V. (2017). Disclosure on Measures to Prevent Corruption Risks: A Study of Italian Local Governments. International Journal of Public Administration. 40(7), 612-624. https://doi.org/10.1080/01900692.2016.1143000.

Fowler, C.J. \& Cordery, C. (2015). From Community to Public Ownership: a Tale of Changing Accountabilities. Accounting, Auditing \& Accountability Journal. 28 (1), 128-153. https://doi.org/10.1108/AAAJ-04-2014-1678

Giosi, A., Testarmata, S. \& Brunelli S. (2010). The Accountability Cycle in Public Agencies: Lessons from Italian Experiences. Milan: Mc Graw-Hill.

Gnecchi, F. (2004). Relations between Local Authorities and Public Utilities Companies. Symphonya. Emerging Issues in Management (symphonya.unimib.it), 1, 58-68. http://dx.doi.org/10.4468/2004.1.06gnecchi

Gray, A. \& Jenkins, B. (1993). Codes of Accountability in the New Public Sector. Accounting, Auditing \& Accountability Journal. 6 (3), 52-67. https://doi.org/10.1108/09513579310042560

Grossi, G. \& Steccolini, I. (2015). Pursuing Private or Public Accountability in the Public Sector? Applying IPSASs to Define the Reporting Entity in Municipal Consolidation. International Journal of Public Administration. 325-334. https://doi.org/10.1080/01900692.2015.1001239

Guthrie, J. (1993). Australian Public Business Enterprises: Analysis of Changing Accounting, Auditing and Accountability Regimes. Financial Accountability and Management. 9(2), 101-114. http://dx.doi.org/10.1111/j.1468-0408.1993.tb00368.x

Haraldsson, M. (2016). Transparency and Accountability Lost? Journal of Accounting \& Organizational Change. 12(3), 254-280. https://doi.org/10.1108/JAOC-01-2015-0006

Heald, D. \& Georgiu G. (2011). The Macro-Fiscal Role of the U.K. Whole of Government Account. Abacus. 47(4), 446-476. http://dx.doi.org/10.1111/j.1467-6281.2011.00348.x

Héritier, A. (2003). Composite Democracy in Europe: The Role of Transparency and Access to Information. Journal of European Public Policy. 10(5), 814-833+849. https://doi.org/10.1080/1350176032000124104

Hood, C. (1991). A Public Management for All Seasons? Public Administration. 69(1), 3-19. https://doi.org/10.1111/j.1467-9299.1991.tb00779.x

Hood, C. (1995). The "New Public Management" in the 1980s: Variations on a Theme. Accounting, Organizations and Society. 20(2-3), 93-109. https://doi.org/10.1016/0361-3682(93)E0001-W.

Janssen, K. (2011). The Influence of the PSI Directive on open Government Data: An Overview of Recent Developments. Government Information Quarterly. 28(4), 446-456. https://doi.org/10.1016/j.giq.2011.01.004

Johnston, J.M. \& Romzek, B. (1999). Contracting and Accountability in State Medicaid Reform: Rhetoric, Theories, and Reality, Public Administration Review. 59(5), 383-399. DOI: $10.2307 / 977422$

Jones, R. \& Pendlebury, M. (1996). Public sector accounting. London: Pitman Publishing.

Kassel, D.S. (2008). Performance, Accountability, and the Debate over Rules. Public Administration Review. 68(2), 241-252. DOI: 10.1111/j.1540-6210.2007.00859.x

Kearns, K.P. (2003). Accountability in a Seamless Economy, in Peters, G. \& Pierre, J. (ed.). Handbook of Public Administration. London: Sage Publications.

Klitgaard, R. (1988). Controlling Corruption. Berkeley: University of California Press 
Kulshreshtha, P. (2008). Public Sector Governance Reform: the World Bank's Framework. International Journal of Public Sector Management. 21(5), 556-567. https://doi.org/10.1108/09513550810885831

Kwan, C.Y., Bali, A.S. \& Asher, M.G. (2016). Organization and Reporting of Public Financial Accounts: Insights and Policy Implications from the Singapore Budget. Australian Journal of Public Administration. 75(4), 409-423. DOI: 10.1111/1467-8500.12228

Lambin, J.J. (2014). Rethinking the Market Economy. Symphonya. Emerging Issues in Management (symphonya.unimib.it), 2, 4-15. http://dx.doi.org/10.4468/2014.2.02lambin

Mir, M.Z. \& Rahaman, A.S. (2007). Accounting and Public Sector Reforms. Accounting, Auditing \& Accountability Journal. 20(2), 237-268. https://doi.org/10.1108/09513570710741019

Mulgan, R. (2000). 'Accountability': An Ever Expanding Concept. Public Administration. 78(3), 555-573. DOI: 10.1111/1467-9299.00218

Mutiganda, J.C. (2014). Circuits of Power and Accountability During Institutionalisation of Competitive Tendering in Public Sector Organisations: A Field Study in Public Care of the Elderly. Qualitative Research in Accounting \& Management. 11(2), 129-145. https://doi.org/10.1108/QRAM-04-2014-0034

Newberry, S. (2015). Public Sector Accounting: Shifting Concepts of Accountability. Public Money \& Management. 35(5), 371-376. https://doi.org/10.1080/09540962.2015.1061180

Ogden, S.G. (1995). Transforming Frameworks of Accountability: the Case of Water Privatization. Accounting, Organizations and Society. 20(2-3), 193-218. https://doi.org/10.1016/03613682(95)95745-I

Pallot, J. (2001). Transparency in Local Government: Antipodean Initiatives. European Accounting Review. 10(3), 645-660. https://doi.org/10.1080/09638180126794

Pályi, A.K. (2015). The Contribution of the State Audit Office to Good Governance and the Renewal of Accounting. Public Finance Quarterly. 60(4), 526- 547. https://www.asz.hu/storage/files/files/public-finance-quarterly-articles/2015/a_palyik_2015_4.pdf

Pepe, C., Mushagalusa Noshombo, J.M. \& Risso, M. (2014). Preventing Corruption in Africa: Emerging Challenges in the Mining Sector of the Democratic Republic of Congo. Symphonya. Emerging Issues in Management (symphonya.unimib.it), 2, 76-92. http://dx.doi.org/10.4468/2014.2.07pepe.mushagalusa.risso

Parker, L. \& Gould, G. (1999). Changing Public Sector Accountability: Critiquing New Directions. Accounting Forum. 23(2), 109-35. DOI: 10.1111/1467-6303.00007

Pollanen, R.N. (2015) Financial Governance Structures and Practices in Canadian Governments. International Journal of Business, Accounting, \& Finance. 9(2), 16-30.

Posner, P.L. (2006). Accountability Institutions and the Policy Process: The United States Experience. OECD Journal on Budgeting. 5(3), 71-96. http://dx.doi.org/10.1787/budget-v5-art19en

Rebora, G. (2004). Global Markets, Leadership and Public Governance. Symphonya. Emerging Issues in Management (symphonya.unimib.it), 1, 5-13. http://dx.doi.org/10.4468/2004.1.02rebora

Reginato, E. (2010). Accountability Perspectives In Italian Municipality Accounting Systems: The Gap Between Regulations And Practices. Public Administration Quarterly. 34(4), 552-590.

Roberts, J. (1996). From Discipline to Dialogue: Individualizing and Socialising Forms of Accountability, in Munro, R. \& Mouritsen, J. (ed.). Accountability: Power Ethos and the Technologies of Managing. London: International Thompson Business Press.

Rodriguez Bolivar, M.P., Navarro Galera, A. \& Alcaide Munoz, L. (2015). Governance, Transparency and Accountability: An International Comparison. Journal of Policy Modeling. 37(1), 136-174. https://doi.org/10.1016/j.jpolmod.2015.01.010

Romzek, B.S. \& Dubnik, M.J. (1987). Accountability in the Public Sector: Lesson from the Challenger Tragedy, Public Administration Review. 47 (3) 227-238. DOI: 10.2307/975901

Rubin, I. (1996). Budgeting for Accountability: Municipal Budgeting for the 1990s. Public Budgeting and Finance. 16(2), 112-132. http://dx.doi.org/10.1111/1540-5850.01071

Salvioni, D.M. \& Bosetti L. (2014). Sustainable Development and Corporate Communication in Global Markets. Symphonya. Emerging Issues in Management (symphonya.unimib.it), 1, 1-19. http://dx.doi.org/10.4468/2014.1.03salvioni.bosetti 
Sinclair, A. (1995). The Cameleon of Accountability: Forms and Discourses. Accounting, Organization and Society. 20(2-3), 219-237. https://doi.org/10.1016/0361-3682(93)E0003-Y

Stewart, J.D. (1984). The Role of Information in Public Accountability', in Hopwood, A. \& Tomkins, C. (ed.). Issues in Public Sector Accounting. London: Phillip Allan Publishers Limited.

Stone, B. (1995). Administrative Accountability in the "Westminster Democracies": Towards a new conceptual framework. Governance. 8(4), 505-526. http://dx.doi.org/10.1111/j.14680491.1995.tb00225.x

Taylor, D.W. \& Rosair, M. (2000). The Effects of Participating Parties, the Public and Size on Government Departments' Accountability Disclosures in Annual Reports. Accounting, Accountability and Performance. 6(1), 77-97.

Torres, L. (2004) Accounting and Accountability: Recent Developments in Government Financial Information Systems. Public Administration \& Development. 24(5), 447-456. DOI: 10.1002/pad.332

Viscusi, G., Spahiu, B., Maurino, A. \& Batini, C. (2014). Compliance with Open Government Data Policies: An Empirical Assessment of Italian Local Public Administrations. Information Polity, 19(3-4), 263-275. https://doi.org/10.3233/IP-140338.

\footnotetext{
Notes

i In literature, the level of political accountability is understood by almost all authors as the principal-agent relationship between politics and the community consisting in the public's ex-post evaluation of the political body on the degree of satisfaction achieved in regard to the goods and/or public services assigned to them and/or delivered by the public sector. An exception is Sinclair (1995), who sees political accountability as the link between employees and the director who in turn is accountable to the political body that is ultimately responsible to citizens. For the purposes of this paper and in relation to the research objective, in agreement with Brunelli et al. (2011), the political accountability level is understood as the accountability process implemented by the administrative level toward the political level
} 